\title{
Can Disinfection Robots Reduce the Risk of Transmission of SARS-CoV-2 in Health Care and Educational Settings?
}

Kathrin Cresswell, BSc, MSc, PhD; Aziz Sheikh, OBE, FRSE, FMedSci

Usher Institute, The University of Edinburgh, Edinburgh, United Kingdom

Corresponding Author:

Kathrin Cresswell, BSc, MSc, PhD

Usher Institute

The University of Edinburgh

Teviot Place

Edinburgh

United Kingdom

Phone: 441316508102

Email: kathrin.cresswell@ed.ac.uk

\begin{abstract}
We explore the opportunities and challenges surrounding the use of disinfection robots to reduce the risk of SARS-CoV-2 transmission in health care and educational settings. Although there is some potential for deploying robots to help with manual cleaning, the evidence base is mixed, and we highlight that there needs to be work to establish and enhance the effectiveness of these robots in inactivating the virus.
\end{abstract}

(J Med Internet Res 2020;22(9):e20896) doi: $\underline{10.2196 / 20896}$

\section{KEYWORDS}

robotics; disinfection; SARS-CoV-2; COVID-19; risk; transmission; virus

SARS-CoV-2 can be transmitted through droplets and contact with contaminated surfaces [1]. To contain the spread, there is a need for more regular and deeper cleaning of indoor surfaces, for example, in schools, care homes, and health care facilities. There is also a need to reduce human exposure to potentially contaminated surfaces. As a result, there is now a greater interest in cleaning and disinfection robots in these settings [2-4]. Such robots are, for example, currently routinely cleaning the Hong Kong metro, and the Smart Field Hospital in Wuhan uses them in an attempt to reduce the spread of SARS-CoV-2 [5,6].

Existing disinfection robots work through a combination of automated or semiautomated processes. They can clean or disinfect floors and surfaces but increasingly focus on disinfecting whole rooms with increasingly complex distribution systems. These most commonly include machines using UV-C light, which works by altering DNA and RNA so that organisms cannot replicate, and vapor and fogging systems that spray chemical disinfectants.

However, despite their increasing use and demand across settings, evidence of their effectiveness is mixed. There is no existing work exploring the effectiveness of disinfection robots in relation to SARS-CoV-2 and other viruses, and the evidence of the impact of UV-C and vapor on health care-associated infections is also limited. In health care settings, both UV-C light and chemical-based disinfection methods (most commonly hydrogen peroxide vapor) do not demonstrate any significant impact on reduced infection rates, although some studies have identified some positive trends and demonstrated a reduction in surface contamination [7-9]. Not surprisingly, UV-C light and chemicals need to touch a surface to be effective, and this may not always be the case-they have issues with shadows, may not reach all areas of concave surfaces, and their effectiveness reduces with distance [10,11]. This work is further complicated by a lack of evidence around how much contamination actually leads to infection and adverse patient outcomes, but there appears to be a general agreement that both techniques are most effective when combined with manual cleaning [12].

Studies investigating cleaning robots using these techniques are limited. The few existing investigations have found that cleaning robots using UV-C light and hydrogen peroxide can deliver some benefits in reducing microbial surface contamination but only when combined with manual cleaning $[13,14]$. The study quality is relatively low for both applications with possible commercial biases.

Deploying the current generation of cleaning and disinfection robots in health care settings, care homes, and schools is, therefore, unlikely to be of major benefit, and there needs be 
work to establish and enhance the effectiveness of these robots in inactivating SARS-CoV-2. In addition to concerns around effectiveness, these devices are expensive at between US $\$ 30,000$ and US $\$ 135,000$ per unit, and organizations need to train staff to deploy and control them [13,15-17]. Disinfectant chemicals and UV-C light can also be dangerous to human health, so people typically need to leave while the robot cleans the room. This is particularly concerning for communal settings but does not preclude the use of UV-C light in enclosed empty spaces. Other factors to consider include disinfection time (some devices take a few hours per room) and issues with physical spaces and navigation (robots are not good at climbing stairs) [14,18].

Floor cleaning robots are likely to be cheaper units that can relatively easily and quickly be adapted (eg, from other types of service robots) and that can focus on one aspect of the physical environment (ie, the floor) while humans work in parallel with them, eliminating issues around disinfection time.
There is, therefore, a need to catalyze the development of floor cleaning robots that can regularly clean communal settings, particularly those with a high risk of transmitting nosocomial infections. These devices can augment manual cleaning, for instance, through supporting an already stretched workforce and through reducing the risk of exposure for cleaning staff and those who work in these settings (eg, doctors, nurses, assistants, teachers), particularly in the context of shortages of personal protective equipment. Some have noted issues with the compliance of cleaning protocols promoting use of these robots, and others have highlighted the importance of effective integration with existing routines and operations [19,20], but this is unlikely to be a significant hurdle in a times of global need. If the current generation of cleaning and disinfection robots are viewed as a panacea to reduce the spread of SARS-CoV-2, the resulting overreliance on their performance may jeopardize lives unnecessarily, but this is an area for urgent development that could help with lockdown exit strategies.

\section{Acknowledgments}

This work was funded by a Scottish Government Chief Scientist Research Grant. The views expressed are those of the authors.

\section{Conflicts of Interest}

None declared.

\section{References}

1. van Doremalen N, Bushmaker T, Morris D, Holbrook M, Gamble A, Williamson B, et al. Aerosol and surface stability of SARS-CoV-2 as compared with SARS-CoV-1. N Engl J Med 2020 Apr 16;382(16):1564-1567 [FREE Full text] [doi: 10.1056/NEJMc2004973] [Medline: $\underline{\text { 32182409] }}$

2. Curcio K. Robots: the future of cleaning? Services Magazine. URL: https://servicesmag.org/online-digital-magazine/ digital-archives/item/291-robots-the-future-of-cleaning [accessed 2020-04-15]

3. Cleaning and disinfection robots market growth is accelerating with a CAGR of 159\%, during 2019-2025. MarketWatch. URL: https://www.marketwatch.com/press-release/cleaning-and-disinfection-robots-market-growth-is-acceleratingwith-a-cagr-of-159-during-2019-2025-2019-09-09?mod=mw quote news [accessed 2020-04-15]

4. Azevedo MA. Hospital-disinfecting robots: Xenex sees surge in orders as COVID-19 pandemic escalates. Crunchbase News. 2020 Mar 25. URL: https://news.crunchbase.com/news/ hospital-disinfecting-robots-xenex-sees-surge-in-orders-as-covid-19-pandemic-escalates/ [accessed 2020-04-15]

5. Metro operator deploys cleaning robot to fight the coronavirus. Metro Report International. 2020 Mar 11. URL: https:/ /www.railwaygazette.com/technology-data-and-business/metro-operator-deploys-cleaning-robot-to-fight-the-coronavirus/ 55995.article [accessed 2020-04-15]

6. Ackerman E. Autonomous robots are helping kill coronavirus in hospitals. IEEE Spectrum. 2020 Mar 11. URL: https:/ /spectrum.ieee.org/automaton/robotics/medical-robots/autonomous-robots-are-helping-kill-coronavirus-in-hospitals [accessed 2020-04-15]

7. Anderson DJ, Chen LF, Weber DJ, Moehring RW, Lewis SS, Triplett PF, et al. Enhanced terminal room disinfection and acquisition and infection caused by multidrug-resistant organisms and Clostridium difficile (the Benefits of Enhanced Terminal Room Disinfection study): a cluster-randomised, multicentre, crossover study. Lancet 2017 Feb;389(10071):805-814. [doi: 10.1016/s0140-6736(16)31588-4]

8. Passaretti C, Otter J, Reich N, Myers J, Shepard J, Ross T, et al. An evaluation of environmental decontamination with hydrogen peroxide vapor for reducing the risk of patient acquisition of multidrug-resistant organisms. Clin Infect Dis 2013 Jan;56(1):27-35. [doi: 10.1093/cid/cis839] [Medline: 23042972]

9. Tran K, McCormack S. Non-Manual Ultraviolet Light Disinfection for Hospital Acquired Infections: A Review of Clinical Effectiveness and Guidelines. 2019 Apr 05. URL: https://www.ncbi.nlm.nih.gov/books/NBK544669/ [accessed 2020-04-15]

10. Yang J, Wu U, Tai H, Sheng W. Effectiveness of an ultraviolet-C disinfection system for reduction of healthcare-associated pathogens. J Microbiol Immunol Infect 2019 Jun;52(3):487-493 [FREE Full text] [doi: 10.1016/j.jmii.2017.08.017] [Medline: 28951015] 
11. Mana TS, Sitzlar B, Cadnum JL, Jencson AL, Koganti S, Donskey CJ. Evaluation of an automated room decontamination device using aerosolized peracetic acid. Am J Infect Control 2017 Mar 01;45(3):327-329. [doi: 10.1016/j.ajic.2016.10.006] [Medline: 27866755]

12. Miller R, Simmons S, Dale C, Stachowiak J, Stibich M. Utilization and impact of a pulsed-xenon ultraviolet room disinfection system and multidisciplinary care team on Clostridium difficile in a long-term acute care facility. Am J Infect Control 2015 Dec 01;43(12):1350-1353 [FREE Full text] [doi: 10.1016/j.ajic.2015.07.029] [Medline: 26362699]

13. Doll M, Stevens M, Bearman G. Environmental cleaning and disinfection of patient areas. Int J Infect Dis 2018 Feb;67:52-57 [FREE Full text] [doi: 10.1016/j.ijid.2017.10.014] [Medline: 29102556]

14. Doll M, Morgan DJ, Anderson D, Bearman G. Touchless technologies for decontamination in the hospital: a review of hydrogen peroxide and UV devices. Curr Infect Dis Rep 2015 Sep;17(9):498. [doi: 10.1007/s11908-015-0498-1] [Medline: $\underline{26252970]}$

15. UVC disinfection robot. Hipac. URL: https://www.hipac.com.au/shop/uvc-disinfection-robot/index [accessed 2020-04-15]

16. Murray A. Coronavirus: robots use light beams to zap hospital viruses. BBC News. 2020 Mar 20. URL: https://www. bbc.co.uk/news/business-51914722 [accessed 2020-04-15]

17. Randall I. Chinese company unveils $\$ 40,000$ hospital robot that uses a combination of UV light and liquid disinfectant spray to kill coronavirus pathogens. Daily Mail. 2020 Mar 27. URL: https://www.dailymail.co.uk/sciencetech/article-8159921/ Chinese-company-unveils-40-000-hospital-robot-disinfectants-against-coronavirus-pathogens.html [accessed 2020-04-15]

18. Hard surface disinfection system from Surfacide. Bates IT. URL: https://www.batesit.co.uk/helios-disinfection-system [accessed 2020-04-15]

19. Fleming M, Major Y, Gryskevicz M, Fife J, Hassmer L, Masroor N, et al. Will audit and feedback drive compliance with UV robot disinfection? Am J Infect Control 2017 Jun;45(6):S51. [doi: 10.1016/j.ajic.2017.04.083]

20. Stibich M. Reduction of healthcare associated infections through the use of pulsed xenon ultraviolet disinfection. SANIMED. 2016 May 13. URL: https://www.sanimed.ro/upload poze documente/files/STUDII\%20CLINICE.pdf [accessed 2020-04-15]

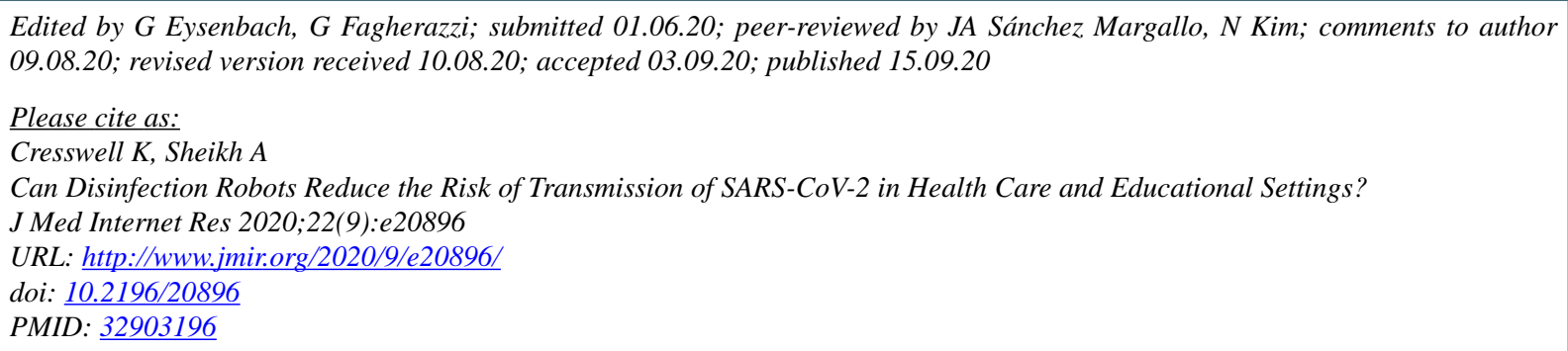

CKathrin Cresswell, Aziz Sheikh. Originally published in the Journal of Medical Internet Research (http://www.jmir.org), 15.09.2020. This is an open-access article distributed under the terms of the Creative Commons Attribution License (https://creativecommons.org/licenses/by/4.0/), which permits unrestricted use, distribution, and reproduction in any medium, provided the original work, first published in the Journal of Medical Internet Research, is properly cited. The complete bibliographic information, a link to the original publication on http://www.jmir.org/, as well as this copyright and license information must be included. 